\title{
Prelude to Revolution in the Church: Diocesan Congresses of Parish Clergy
}

\author{
Gregory L. Freeze
}

For citation: Freeze G.L. Prelude to Revolution in the Church: Diocesan Congresses of Parish Clergy. Vestnik of Saint Petersburg University. History, 2019, vol. 64, iss. 4, pp.1272-1286. https://doi.org/10.21638/11701/spbu02.2019.407 (In Russian)

Recent scholarship has significantly enhanced our knowledge of the Russian Orthodox Church in 1917, including the role of diocesan congresses of clergy and laity (eparkhial'nye s"ezdy dukhovenstva i mirian) in the first months after the February Revolution. As yet, however, it has been given relatively little attention to the prehistory of the congresses that were established by the seminary reform of 1867 . This study seeks to fill that gap and suggests the following theses. First, in the period from their establishment in 1867 to the revolution of 1905-1907, the congresses had a very uneven history, but essentially failed to expand their competence and composition, especially under the chief procurator K. P. Pobedonostsev. Second, in the 1905-1907 revolution, many congresses proved highly progressive, endorsing the "liberation movement" and demanding far-reaching reform in the Church. Some supported empowerment of the parish (control over parish finances, even the right to choose local clergy). Third, support for empowerment of the laity declined after 1905, largely in response to the growing assertiveness of the laity. In the spring of 1916, most had become openly skeptical of parish reform and empowerment of the laity.

Keywords: Russian Orthodox Church, clergy, parish, diocesan congress, 1905 revolution, parish reform, Holy Synod.

\section{Прелюдия к революции в Церкви: епархиальные съезды приходского духовенства}

\section{Грегори Л. Фриз}

Для цитирования: Freeze G. L. Prelude to Revolution in the Church: Diocesan Congresses of Parish Clergy // Вестник Санкт-Петербургского университета. История. 2019. Т. 64. Вып. 4. С.12721286. https://doi.org/10.21638/11701/spbu02.2019.407

Новейшая историография основательно расширила наше знание о Русской православной церкви и ее роли в революционном 1917 г., в частности об епархиальных съездах

Gregory Freeze - PhD, Professor of History, Brandeis University, GF11, Waltham, Massachusetts, USA; Visiting Research Fellow, St. Petersburg State University, 7-9, Universitetskaya nab., St. Petersburg, 199034, Russian Federation; freeze@brandeis.edu

Грегори Фриз - PhD, профессор истории, Брандейский университет, США, Уолтем, Массачусетс, США; приглашенный исследователь, Санкт-Петербургский государственный университет, Российская Федерация, 199034, Санкт-Петербург, Университетская наб., 7-9; freeze@brandeis.edu

This research was supported by grant No. 15-18-00119 from the Russian Science Foundation.

Исследование выполнено при поддержке гранта Российского научного фонда № 15-18-00119.

(c) Санкт-Петербургский государственный университет, 2019 
духовенства и мирян в первые месяцы после Февральской революции. Но до сих пор мало внимания было обращено к предыстории епархиальных съездов после того, как они были созданы семинарской реформой 1867 г. Данная работа пытается заполнить эту лакуну и выдвигает следующие тезисы. Во-первых, в период от создания съездов в 1867 г. до революции 1905-1907 гг. съезды работали очень нестабильно, особенно во время обер-прокурорства К.П. Победоносцева. Во-вторых, во время революции 19051907 гг. съезды проявили крайне прогрессивные тенденции (например, поддержали «освободительное движение») и потребовали фундаментальную реформу Православной церкви. Нередко съезды духовенства высказывали свою поддержку приходской реформе (местный контроль над финансами, даже определенная роль в выборе клира в своей церкви). Такая поддержка расширения прав и возможностей мирян пошла на убыль после 1905 г., в основном в ответ на их растущую напористость. Весной 1916 г. целый ряд собраний духовенства проявлял открытый скептицизм по отношению к приходской реформе и расширению уполномочий мирян.

Ключевые слова: Русская православная церковь, духовенство, приход, епархиальный съезд духовенства, революция 1905 г., приходская реформа, Святейший синод.

In the years preceding the revolutions of 1917 the Russian Orthodox Church - like the state and society - found itself mired in a profound crisis. Indeed, the Church and general crises intersected: the protest against autocracy and privilege, and the demand for democratization and social justice spawned parallel movements in the Church ${ }^{1}$. Popular cries - "we are not slaves", "down with the despots" - came now from priests and parishioners, not just workers and peasants. The Church crisis seemed especially ominous because it accompanied a perceived decline in popular piety or at least loyalty to Orthodoxy, whether because of a rise in disbelief or the proselytizing of other beliefs (especially after the decree on freedom of confession on 17 April 1905). To many, the Church was ill-prepared to cope with these challenges, even more so after the Great Reforms of the 1860s that did more to aggravate than solve problems. The mix of reforms in the parish, seminary, and estate (soslovie), in the view of many, undermined the Church's infrastructure and lowered educational standards among parish clergy, without increasing the promised vocations from other social classes or improving the clergy's material support ${ }^{2}$.

This study focuses on an important actor in the Church crisis - the diocesan congress of parish clergy. Created by the seminary reform of $1867^{3}$, the congress was responsible for overseeing and augmenting the funding for the ecclesiastical schools (dukhovno-uchebnye zavedeniia $)^{4}$ that primarily served the children of parish clergy. Although the congresses sometimes sought to expand their competence (especially in the 1870s), thereafter the chief procurator K. P. Pobedonostsev acted to curtail such ambitions and even proposed

1 Throughout this article a distinction is drawn between the "Church" (institution) and "church" (the local parish), the purpose being to highlight the growing tension between the two that, by 1917, culminated in the shift of power from "Church" to "church" (which was then made the foundation of the Bolshevik decree "On the Separation of Church and State" in January 1918).

${ }^{2}$ For an overview of the Great Reforms, see the discussion and references in: Freeze G. L. The Parish Clergy in Nineteenth-Century Russia: Crisis, Reform, Counter-Reform. Princeton, 1983.

3 Polnoe sobranie zakonov Rossiiskoi Imperii, 2-e sobranie. St. Petersburg, 1871. Vol. 42, no. 44571.

4 The collective term "ecclesiastical schools" refers to the elementary school (dukhovnoe uchilishche) and seminary (dukhovnaia seminariia); its use helps to avoid any confusion with the "parish school" (tserkovno-prikhodskaia shkola) that proliferated in the last decades of the ancien régime, especially under the strong initiative from Pobedonostsev. 
to abolish the congresses (but met with overwhelming opposition, even from conservative bishops) ${ }^{5}$. The congresses thus survived as an estate institution (serving the needs of the clerical estate, dukhovnoe soslovie) and did not number lay believers among its delegates. Revolutions in 1905 and still more in 1917 changed all that: the congress became an important factor in Church politics providing a forum in which the parish clergy (and, in 1917, lay delegates as well) united to defend their interests and impose their will.

The diocesan congress, however, has received little scholarly attention, a neglect that reflects the general secularist bias not only in Soviet and Western historiography ${ }^{6}$ but even in the post-Soviet era, when most research has concentrated on the Church in 1917 and afterwards ${ }^{7}$. As a result, the diocesan congresses before 1917 has received scant attention ${ }^{8}$. For the most part, the research has tended to focus on Church-state relations, clerical elites, and the influence of the notorious Grigorii Rasputin?.

This study examines the diocesan congress in the last decades of the ancien régime prior to the revolutions of 1917. It demonstrates how parish clergy, especially during the revolution of 1905-1907, used the congress to assert their interest in fundamental Church reform. The mood and resolutions varied among congresses, but most were markedly liberal and reformist, even "renovationist" (to use a term that became pejorative in later decades). Significantly, however, the parish clergy — despite their "liberalism" - exhibited a

\footnotetext{
${ }^{5}$ See the discussion and references in: Freeze G. L. The Parish Clergy in Nineteenth-Century Russia... P. 435-436.

${ }^{6}$ Compared with scholarship on religion and churches in Western Europe, the historiography for the
} Russian Orthodox Church is exceedingly weak. Before 1917, research on the Russian church was highly confessionalized (that is, virtually monopolized by those serving the Church and subject to ecclesiastical censorship); Soviet historiography (1917-1991) was profoundly anti-confessional because of an official antireligious policy. Although Soviet historians produced works with empirical value and showed far more autonomy and originality during perestroika, serious scholarship on the Church only commenced in the 1990s - both in Russia and abroad. However, interest has focused mainly on the Soviet era and on clerical elites and their institutions, with little attention to priests and parishioners.

7 See: Leont'ev P. Ia. Revoliutsiia v tserkvi: s'ezdy dukhovenstva i mirian v 1917 godu // Tserkov' v istorii Rossii. 1998. Vol.2. P.214-248; Rogoznyi P.G.: 1) "Tserkovnaia revoliutsiia" i vybory arkhiereev v 1917 g. // Istoricheskie zapiski. 2004. Vol.7/125. P.275-322; 2) Tserkovnaia smuta v Orlovskoi eparkhii v 1917 g. // Riurik. 2004. No. 4. P. 17-33; 3) Tserkovnaia revoliutsiia v Tverskoi eparkhii v 1917 g. (k izucheniiu sotsial'no-politicheskoi bor'by v Rossiiskoi Pravoslavnoi tserkvi) // Provintsial'noe dukhovenstvo dorevoliutsionnoi Rossii. 2005. Vol. 1. P.92-106; Babkin M. A.: 1) Prikhodskoe dukhovenstvo Russkoi Pravoslavnoi Tserkvi i sverzhenie monarkhii v 1917 godu // Voprosy istorii. 2003. No. 6. P.53-70; 2) Dukhovenstvo Russkoi pravoslavnoi tserkvi i fevral'skaia revoliutsiia 1917 g. Moscow, 2002; Firsov S. L. Revoliutsiia 1917 g. i popytki "demokratizatsii" Russkoi tserkvi // Tserkovno-obshchestvennyi vestnik. 2000. No. 6/7. P. 196-208; Evtuhov C. The Church's Revolutionary Moment: Diocesan Congresses and Grassroots Politics in 1917 // Russian Culture in War and Revolution, 1914-1922 / eds M. Frame, B. Kolonitskii, S. G. Marks, M. Stockdale. Bloomington, 2014. Vol. 1. P.377-402; Kail' M. V. "Revoliutsiia v tserkvi”: diskussii o tserkovnoi reforme i smolenskii eparkhial'nyi s'ezd dukhovenstva i mirian 1917 g. // Tserkovno-istoricheskii vestnik. 2007. No. 14. P. 163-173.

8 Prerevolutionary works are useful but limited. For the pre-revolutionary phase, see: Kuliasov A. Kazanskie eparkhial'nye s"ezdy za piat'desiat' let. Kazan', 1913; Bogoiavlenskii V. Eparkhial'nye s"ezdy dukhovenstva, ikh deiatel'nost' i znachenie. Omsk, 1902; Beliaev V. et al. Eparkhial'nye s'ezdy. St. Petersburg, 1908. Recent scholarship has shown little interest in the congresses; an exception is short article by: Smirnova I. E. Eparkhial'nye s'ezdy // Vestnik Tverskogo gosudarstvennogo universiteta. Seriia: Istoriia. 2012. No. 1. P. 111-119.

9 To be sure, there are important exceptions, such as: Leonteva T.G. Vera i progress: pravoslavnoe sel'skoe dukhovenstvo Rossii vo vtoroi polovine XIX v. - nachale XX v. Moscow, 2002; Beglov A. L. Gosudarstvennaia duma i proekt organizatsii pravoslavnogo prikhoda v 1911 g. // Rossiiskaia istoriia. 2016. No. 5. P. 87-92. 
striking ambivalence toward their parishioners. While priests were generally disposed to enhance greater parish control over local finances, they were reluctant to allow the laity to select and remove local clergy. That qualified liberalism gained momentum after 1905 because of the parishioners' growing assertiveness in 1905-1907 and afterwards. Laicization (empowerment of the laity) thus proved a two-edged sword. On the one hand, it appeared to be tantalizing strategy to mobilize and energize believers and thereby provide an effective, needed antidote to the purported "secularization" and decline of traditional piety in the popular classes. On the other hand, laicization posed a direct threat to the social and economic interests of the clerical estate: parishioners increasingly resented the use of parish revenues to fund ecclesiastical schools (which continued to serve almost exclusively the clergy's children) and demonstrated a willingness to reduce the clergy's material support and violate the security of their very appointment.

In the decades after 1867, as the Church extended the seminary reform to more and more dioceses, bishops convened congresses of local clergy to supervise diocesan schools, partly to provide a parental role in oversight, partly to find ways to augment the schools' meager budgets (which caused the horrendous privation described in famous bursak literature of the 1860s). The congress, however, lacked precise rules on frequency, competence, and composition; all that was left to the discretion of the local bishop ${ }^{10}$. The congress, like the schools, reflected the pervasive soslovnost' of the Church and clergy; the 1867 reform notwithstanding, the schools continued to service mainly the children of the parish clergy ${ }^{11}$ and, by extension, to sustain the hereditariness of the parish clergy ${ }^{12}$. The congresses did assume some additional tasks, but these too pertained to the special needs and interests of the clergy (e.g., pensions for retired clergy, and welfare assistance for clerical widows and orphans). The diocesan bishop had full authority over the congress, convened them at his discretion (sometimes at considerable intervals), controlled its agenda, and edited its resolutions ${ }^{13}$.

While practice therefore varied widely, the record of the diocesan congress in Kazan was typical. The frequency of convocation was very uneven: in 1867-1881, the congress met almost annually, in 1882-1894 - just one year in four, but after 1895 - again met every year. The first period reflected a burst of activity to improve the newly reformed seminary; the next period corresponded to the conservative counter-reforms, especially chief procurator K.P. Pobedonostsev's aversion to the congresses (as too democratic and posing

${ }^{10}$ For complaints about the unclear legal status of the diocesan congress, see the comments (otzyvy) from diocesan authorities in Voronezh, Vladimir, Astrakkhan, Arkhangel'sk, Riga, Kostroma, and Moscow dioceses: Otzyvy eparkhial'nykh arkhiereev po voprosu o tserkovnoi reforme, 2 vols. Vol. 1. Moscow, 2004. P. 189-190, 293-302, 367-370, 414-415, 908-911; Vol. 2. P. 147-149, 393-394.

11 In 1913-1914, the clerical estate (dukhovnoe soslovie) still dominated the social composition of the seminarywhere 82.9 percent of the students were clerical sons. The proportion in diocesan girls' schools was even higher (87.1 percent). Vsepoddanneishii otchet ober-prokurora Sviateishego Sinoda po vedomstvu pravoslavnogo ispovedaniia za 1914 god. Petrograd, 1916. Prilozhenie. P. 68-71, 112-115.

12 In 1904, only 3 percent of the 47,743 priests in the Russian Empire were of non-clerical origin (Mironov B. N. Social History of Imperial Russia 1700-1917. 2 vols. Vol. 1. Boulder, 2000. P. 229). Although monasticism had a higher proportion from other social estates, the episcopate held an advanced degree from the ecclesiastical academy and came mostly from the clerical estate. See: Plamper J. The Russian Orthodox Episcopate, 1721-1917: A Prosopography // Journal of Social History. 2000. Vol. 34. P. 5-34.

${ }^{13}$ On rare occasions, however, a congress did seek to expand its competence. A striking example came in Tver diocese in 1876, when the congress proposed to reform the office of local superintendent (blagochinnyi) by replacing the practice of episcopal appointment with election by clergy in that district. See: Smirnova I.E. Eparkhial'nye s"ezdy. P. 114. 
an impediment to untrammeled administrative control); the third phase represented a response to the rising tempo of seminary unrest and urgent need to find solutions. The composition changed as well, becoming less democratic: until 1893 the Kazan congress consisted of representatives elected by parish clergy, but in 1894-1904 consisted solely of superintendents (blagochinnye), all appointed by the local bishop. As in other dioceses, the Kazan congress was un-budgeted and un-institutionalized; it had neither an executive organ nor its own staffing. Characteristically, a congress convened in 1894, but a later inquiry revealed that "there are no journals" - that is, the congress left no public record of its decisions, much less concrete directives for their implementation. Despite all these weaknesses, the Kazan congresses did expand their role from diocesan schools (the core responsibility) to include such matters as the "distribution of superintendents' districts" (1880), compensation for superintendents (1881), deliberations "about parish schools and good order in the diocese" (1885), a statute for the pension fund (1895), and "electrical lighting in churches" $(1900)^{14}$.

However, most congresses failed to expand either their competence or their composition. As a result, liberal priests came to regard the congress as yet another "unrealized promise of the Great Reforms." To quote a blunt critique by a disillusioned parish priest: "For the congress of the clergy, the last two decades of the nineteenth century and first years of the twentieth were a time of incremental extinction. The congresses were rarely convoked; in some dioceses the congresses of delegates from the clergy turned into meetings of the superintendents [appointed by the bishop]; the topics of discussion at the congresses have been reduced to the very minimum; the clergy could discuss only economic questions, but even in this narrow sphere they often had to submit to decisions that had been taken in advance"15.

The revolution of 1905-1907 was to have a profound impact on the Orthodox Church in general and the congresses in particular. A key dynamic was the explosive unrest that swept through seminaries (encompassing 26 of 57 schools by the end of 1905) ${ }^{16}$, and that even led to the formation of an empire-wide seminarian union. The radical activities of the seminarians inevitably triggered the involvement of their clerical fathers: the harsh measures to quash seminary disorders (up to summary expulsion and exclusion from secular schools) naturally caused their fathers in the parish clergy to become involved ${ }^{17}$. A second critical development in 1905 was the decree on freedom of conscience (17 April 1905), which decriminalized "apostasy" and made the Church vulnerable to mass conversions to other confessions. The decree elicited much criticism from the Church, but also provided an impulse to reform the Church and make it better fit to compete with other confessions. In the view of many, that meant revitalizing the parish - giving the laity more authority and incentive to defend and promote Orthodoxy at the grassroots. A third

14 Kuliasov A. Kazanskie eparkhial'nye s'ezdy za piat'desiat' let. P. 12-14.

15 Dobronravov $V$. Komissiia dlia predvaritel'noi razrabotki voprosov, podlezhshchikh obsuzhdeniiu na eparkhial'nykh s'ezdov // Vladimirskie eparkhial'nye vedomosti. 1906. No. 4. P. 57.

16 Pavlenko T.A. Protestnoe dvizhenie pravoslavnykh seminarii v period Pervoi Russkoi Revoliutsii 1905-1907 gg. Diss. ... kand. ist. nauk. St. Petersburg 2009. P. 15. - For materials on radical seminarians and the formation of a "union of seminarians", see: Gosudarstvennyi arkhiv Rossiiskoi Federatsii (GARF). F. 102. G. 1905. D. 1000. Ch. 10; Rech'. 1906. No. 1. P.7; GARF. F. 102. Op. 8. D. 89 (two vols.).

17 For the case of Vladimir diocese, see: Freeze G.L. Priests and Revolution: The Parish Clergy of Vladimir in 1905 // Rethinking the Russian Revolution of 1905 in Transcultural Perspective. Eds F. Fischer von Weikersthal et al. Bloomington, 2013. 
formative influence on the Church was the liberation movement itself, which led many clergy to become engaged and, in some cases, to even actively support radical currents among the laity ${ }^{18}$.

The revolution thus generated a series of "extraordinary" diocesan congresses that now had a far-reaching agenda. Some prelates acceded to demands for a congress or even, as in Riga diocese, provided the initiative in their convocation. Critical support also came from the Synod, which had marginalized Pobedonostsev and, under Metropolitan Antonii (Vadkovskii), launched a campaign for Church reform and convocation of a national Church council. The Synodal initiative was a direct response to the impending decree on freedom of conscience: nearly two weeks before it became public, the Synod secretly gave diocesan authorities advance warning and recommended that they convene diocesan congresses or assemblies to deliberate how the Church should respond to the challenge ${ }^{19}$. As the revolutionary crisis deepened, on 18 November 1905 the Synod issued a new directive to convoke such meetings and even to permit a radical expansion of its composition by including laity: "The Holy Synod gives its blessing to the convocation of assemblies at the level of a superintendent, district, and diocese to discuss questions arising about pastoral activity, with the possibility (if it seems necessary) to include laity in these gatherings." Although the Synod was careful not to violate the bishop's prerogatives (convocation remained at the discretion of the local bishop), the resolution contained a blank check on the agenda and, more striking still, even authorized the inclusion of laity ${ }^{20}$. Although short of a rumored "all-Russian congress of clergy" sought by some $e^{21}$, the Synod resolution impelled many bishops to convene a diocesan assembly or some form of informal gatherings to address critical issues.

The bishop of Vladimir diocese, Nikon (Sofiiskii), convened both the informal assemblies and a diocesan congress ${ }^{22}$. Nikon himself was a former priest, who had widowed, taken monastic vows, and earlier served as rector of the Vladimir seminary; he thus had personal ties to the clerical "fathers and sons" who had become embroiled in seminary disorders in $1905^{23}$. But he was a moderate conservative ${ }^{24}$ and initially resisted pleas to summon an extraordinary diocesan congress (citing the shortness of time and travel diffi-

18 Based on data in central archives (Synodal and chief procuratorial chancelleries), 247 clergy - or approximately 0.4 percent of all priests - were eventually prosecuted for "revolutionary" activities. See the statistical analysis in: Pisiotis A.K. Orthodoxy versus Autocracy: The Orthodox Church and Clerical Political Dissent in Late Imperial Russia, 1905-1914. PhD. diss. Georgetown University, 2000. - That is certainly an incomplete count of clerical radicals: given the inevitable underreporting (diocesan authorities tended to provide information only on the most egregious cases, and the chief procurator relied heavily on denunciations from the Ministry of Interior), the incidence of clerical radicalism was no doubt higher.

19 Rossiiskii gosudarstvennyi istoricheskii arkhiv (RGIA). F.796. Op.187. G.1906. D.6972. L.22$23 \mathrm{ob}$.

20 Opredeleniia Sv. Sinoda // Tserkovnye vedomosti. 1905. No. 48 (26 Nov.). P. 523-525.

21 Otklik dukhovenstva // Tserkovnyi vestnik. 1905. No. 10 (10 March). P.318.

22 For an overview, see: Freeze G. L. Priests and Revolution... P. 19-38.

23 Preosviashchennyi Nikon, episkop vladimirskii i suzdal'skii // Vladimirskie eparkhial'nye vedomosti. 1904. No. 24. P.703-713.

${ }^{24}$ Flabbergasted by news of the October Manifesto, Nikon hastily sent a telegram to the Synod asking that it confirm the veracity of such reports: "A telegram has been received with the manifesto about the grant of freedom of press, speech, conscience, assembly, unions, and the conferral of legislative power to a state duma, and the establishment of ministerial responsibility. Is it true that such a manifesto was issued?" RGIA. F.796. Op. 186. G. 1905. D. 894. L. 4 (telegram dated 19 October 1905). 
culties) ${ }^{25}$. However, even before the Synod authorized clerical meetings, Nikon had organized informal "assemblies" (sobraniia) at his residence to hear formal reports (doklady) by local priests and to discuss key issues. And all this was given extensive coverage in the diocesan paper. The assemblies were surprisingly uninhibited; the session on 8 November, for example, had a general discussion of the liberation movement and the proper response of the Church and clergy:

But if the pastors closely carefully look into the life around them, they cannot fail to be convinced of the need for fundamental reforms in all spheres of this life, and the condition of the church and clergy itself are in no less need of such reforms. Hence it is most natural for the pastors of the Russian Church to be on the side of the liberation movement, not against it, and to help eliminate the worst extremes and to inject the foundational Christian commandment, "love thy neighbor"26.

Although the assemblies declined to endorse any one political party, they affirmed the clergy's duty to give counsel: "The pastors of the Church, as was stated at the meetings, are not to become involved in party agitation. Rather, in making judgments about the program of this or that party, they are to be guided by Orthodox Christian teachings and to exert an influence on their flock through their pastorship, not through a party program." The assembly did make an exception to this "non-party" position: it explicitly repudiated the "black-hundredist" Union of Russian People (despite the latter's populist social program). At the same time, the assembly affirmed the need to resolve the agrarian question, declaring that "more radical measures are needed - such as the allocation of land to the peasants from the reserves of state land"27.

In late November, after the Synodal instruction, Bishop Nikon followed the example of other prelates and convened an extraordinary diocesan congress. The sessions received extensive coverage, not only in the diocesan gazette, but also in the local newspapers ${ }^{28}$. The congress first turned its attention to the seminary crisis, adopting proposals to modernize the curriculum and facilitate mobility - which their seminarian sons demanded so that they could more easily transfer to secular schools and then pursue a career outside the Church. Like the assemblies that met earlier, the congress discussed "how are the pastors of the Church to respond to the liberation movement" and "to the propaganda of various political parties".

Most important, however, the congress devoted considerable time to discussing the question of reform in the Church itself. A major issue was "democratization" of Church governance, not only application of the electoral principle (vybornoe nachalo) but also the inclusion of laity along with clergy in local and diocesan congresses (with specific discussion of "the number of votes" to be allocated to the laity) ${ }^{29}$. The clerical delegates at the

\footnotetext{
$23 \mathrm{ob}$.

${ }^{25}$ Gosudarstvennyi arkhiv Vladimirskoi oblasti (GAVO). F. 556. Op. 1. D. 4423. L.21, 22-22 ob., 23-

26 Sobranie v dome Ego Preosviashchenstva // Vladimirskie eparkhial'nye vedomosti, 1905. No. 22. P. 683 .

27 Sobraniia v dome Ego Preosviashchenstva // Vladimirskie eparkhial'nye vedomosti, 1906. No.1. P. 16-17.

28 Zhurnaly ekstrennego s"ezd upolnomochennykh ot dukhovenstva Vladimirskoi eparkhii i roditelei vospitannikov Vladimirskoi dukhovnoi seminarii // Vladimirskie eparkhial'nye vedomosti. 1905. No.23. P.1-16; No.24. P. 17-39. For coverage in a local newspaper, see: Kliaz'ma. 1906. No. 7 (9 Jan.). P.3; No. 14 (16 Jan.). P. $1-2$.

${ }^{29}$ GAVO. F. 556. Op. 1. D. 4423. L. 6-6 ob.
} 
congress favored far-reaching democratization, even at the parish level: "the election of parish pastors and other members of the local clerical staff was recognized as possible" a view that would fade markedly in subsequent years. The congress was far more categorical about the democratization of diocesan administration, resolving that "superintendents should be elected for three-year terms by the clergy in that district" and that "members of the diocesan consistory should be elected by diocesan congresses for a five-year term"in both cases, ending the current practice of appointment by the local bishop ${ }^{30}$. The congress vented its spleen on the consistory: "In view of the diocesan clergy's dissatisfaction with their treatment by the members and staff of the consistory, the congress resolved to ask His Grace to renew the composition of the consistory and its chancellery" 31 . The congress also raised a long-standing complaint about the inadequate and unseemly material support accorded to the clergy, but offered no specific solution on how to address the issue. Finally, the congress adopted a litany of other proposals that were being widely circulated among clerical reforms, such as a ban on state medals for clergy (to avoid identifying priests as civil servants), abolition of the censorship committee that previewed their sermons, annulment of the penalties imposed for voluntary defrocking (the only real option for widowed priests with young children $)^{32}$, and the need to recruit clerical candidates from other social estates.

These liberal resolutions went too far for Bishop Nikon, who felt obliged to edit the texts before permitting their publication in diocesan gazette and - doubtless - dissemination by the ecclesiastical press around the country ${ }^{33}$. The manuscript text of the congress's sessions contains the original resolution, along with Nikon's editing. For example, in the resolution on the diocesan newspaper the congress wanted to create a virtual "Church public community" (tserkovnaia obshchestvennost'), but Nikon deleted the more inflammatory passages:

Bearing in mind that the editor N. V. Malitskii, in addition to a weekly [rather than biweekly] publication of the gazette beginning in 1906, has promised to change somewhat the content and character of the local organ (by transmitting brief accounts about the course of the politieal and chureh-social life during the previous week, information from the general diocesan life, and extracts from journals and newspapers of interest for the clergy), the clergy is to be given the opportunity to take a broad participation in collaborating with this organ" 34 .

\footnotetext{
30 Ibid. L. 9 ob.

${ }^{31}$ Ibid. L. 10 ob.

${ }^{32}$ For origin of these penalties, see the discussion in: Freeze G. L. The Parish Clergy in NineteenthCentury Russia... P. 150-151, 217-220.

33 Even earlier, but especially in 1905, diocesan papers published reports and resolutions of s"ezdy elsewhere - hence the demand that the local eparkhial'nye vedomosti focus on contemporary issues. See, for example, this detailed - and typical — overview in the Riga diocesan gazette: O preobrazovanii tserkovnoprikhodskoi zhizni. Inoeparkhial'nye izvestiia // Rizhskie eparkhial'nye vedomosti. 1905. No. 17 (1 Sept.). P.781-786; No. 18 (15 Sept.). P. 838-848. - Not all diocesan papers were so expansive and disposed to engage contemporary questions and came under growing pressure to do so. In Vladimir diocese, for example, the clergy became increasingly discontented with the local diocesan gazette, a sentiment reflected in this complaint by one local priest: "The [Vladimir] diocesan gazette is an organ created to serve the interests of the local clergy and the diocese, but it enjoys little favor among its readers. Everyone has to hear about the paltry, irrelevant content of its material, about its lack of engagement in life, and - most important - about a fatal forgetting of its direct purpose: to be the living voice for the needs and demands of this diocese". (Eparkhial'nye vedomosti i ikh sotrudniki // Vladimirskie eparkhial'nye vedomosti. 1903. No. 16. P. 435-445.)

${ }^{34}$ GAVO. F. 556. Op. 1. D. 4423 . L. 3 ob. -4.
} 
Nikon also excised the text of the resolution on the liberation movement:

The clergy must not remain on the sidelines, but should be sympathetic toward the liberation movement in the spirit of the manifesto of 17 October, without joining any political party, but approving in each what is good and condemning what is bad from a Christian point of view. [From a practical point of view, the elergy should be more sympathetic to a moderate peasant party, approving its program, with the exception of certain extreme points.] ${ }^{35}$

Such censorship shows the need to use the original text in the diocesan archives; what was printed could - even under a moderate like Nikon — differ significantly from what transpired at the sessions.

Censorship notwithstanding, the text printed in the diocesan gazettes did record stormy proceedings at the congress, even direct confrontations between the bishop and local clergy. Such was the case for the diocesan congress in Viatka in August-early September 1905. The first clash erupted when Bishop Filaret (Nikol'skii) instructed the congress to include not only parish clergy but diocesan missionaries - whom priests intensely disliked as a drain on parish resources and, many suspected, as spies for diocesan authorities. When the congress voted to deny admission to the missionaries (or even to allow them to attend as nonvoting observers), Filaret was furious: "The diocesan hierarch has not yet been stripped of his power to decide questions involving the religious and moral needs of the diocese, or pastoral and missionary questions. Invite to the congress other people, who are experienced and trustworthy, giving them a vote along with the priestly deputies." That was not the only conflict: the congress challenged the right of diocesan authorities to impose levies on parishes - a major bone of contention between the diocese (which relied on parish funds to finance ecclesiastical schools and administration) and the clergy and laity (who resented the fact that they had no control over how these funds were used). The congress therefore adopted a resolution declaring it "desirable that no general diocesan sums, or remains from them, be expended without the knowledge and consent of the entire diocesan clergy in the form of the diocesan congresses." The delegates also adopted a scathing resolution on the diocesan consistory and refused to increase diocesan subsidies, adding insult to injury with this explanation: "The consistory, as a governmental institution, should be supported by government funding." The congress even volunteered that "His Grace is not acting on the basis of the law" and denounced the "bureaucratic regime in church-social life." That declaration underlay the congress's categorical affirmation of "self-governance, with the application of the electoral principle (vybornoe nachalo) in local parish life and in the domain Church administration." Like clergy elsewhere, that democratization entailed "the indispensable participation of the laity" and was comprehensive, specifically including "the election of parish clergy, bishops, members of Church Councils (pomestnye sobory), and the Synod"36.

35 Ibid. L. 7.

36 Protokoly i zhurnaly s"ezda dukhovenstva Viatskoi eparkhii za 1905 god // Viatskie eparkhial'nye vedomosti. 1905. No. 19. P.59, 62-63; No.23. P.240, 284-285. - Relations in the diocese remained highly confrontational. In late November, several priests in Viatka distributed a hectograph, bewailing the fact that "the bishop of Viatka, evidently misled by someone, has come to oppose the last diocesan congress that was comprised of representatives from the clergy." RGIA. F. 796. Op. 187. D. 6677. L. 26 ob. 
Clergy elsewhere expressed similarly radical views ${ }^{37}$. The parish clergy in Yalta, for example, convened - at their own initiative! - and on 21 November 1905 adopted a resolution that warmly endorsed the liberation movement: "We deem the Russian liberation movement to be just and consistent with divine commandments, and we cannot fail to welcome it." The Yalta clergy also held Church authorities partly responsible for the current crisis: "We express regrets that, at this alarming time, higher ecclesiastical authorities have conducted, and conduct, themselves without sufficient zeal (partly as a consequence of the abnormal order in the Church, partly at their own fault), and they do not clearly explain their position with respect to the events now occurring; nor do they speak to the government about the needs of the people; nor do they see the need to enter into the closest possible ties with priests and other members of the Church" 38 . The issue of parish empowerment was critical, and moderates in the parish clergy voted overwhelmingly to enhance the laity's control over parish finances and even to give some role in the selection of local clergy ${ }^{39}$. The resolution by a city gathering of clergy and church elders in Arkhangel'sk was unequivocal: "The assembly recognizes that, for purposes of a complete, fundamental transformation of the contemporary parish into a unique, autonomous church community (tserkovnaia obshchina), which is self-governing, cohesive, and unified, it is necessary to grant as soon as possible the ancient rights that belonged to the parish: the power to control all church funds and to elect members of the clerical staff" $"$.

The diocesan congress in Riga was particularly radical and exerted a major influence on other dioceses ${ }^{41}$. Archbishop Agafangel (Preobrazhenskii) played a key role, actively promoting its convocation and even calling the congress a "church council" (sobor) both because of its comprehensive agenda (far beyond that of the previous congresses of clergy) and because of its composition (which included not only priests, but also deacons, sacristans, and even "some laymen known for their piety and devotion to the Orthodox Church, their knowledge and deeds on behalf of Orthodoxy, or deep familiarity with the local conditions prevailing in this region"). The archbishop explicitly invited the "sobor" to consider the two core issues in the "parish question": the parishioners' role in the selection of local clergy and their control over local finances. The "sobor" did not disappoint: it not only confirmed the parishioners' rights in these matters but even argued for the inclusion of female parishioners:

37 See, for example, the resolutions by the diocesan congress in Tambov: Po eparkhiiam // Tserkovnoobshchestvennyi vestnik. 1906. No. 43 (13 Oct.). P. 1441. - For analogous materials on the congresses that convened in Chernigov and St. Petersburg, see: RGIA. F. 796. Op. 187. D. 921 and Op. 442. D. 2105. L. 17 ob. See also the overview in: Beliaev V. et al. Eparkhial'nye s"ezdy. P. 69-76, 89-102.

38 RGIA. F. 796. Op. 187. D. 6571. L. 3-4; Tserkovno-obshchestvennaia zhizn'. 1906. No. 10. P. 374-375.

39 Diocesan levies constituted a major issue, partly because so much was used for the benefit of the clerical estate (e.g., the ecclesiastical schools that mainly enrolled the clergy's children), partly because of the magnitude (17.75 to 35.45 percent, depending on the diocese). See: Beglov A. I. Pravoslavnyi prikhod Rossiiskoi imperii kak ob’ekt fiskal'noi politiki svetskikh i tserkovnykh vlastei v kontse XIX - nachale XX v. // Vestnik PSTGU. II: Istoriia. 2014. Iss. 3 (37). P. 56-81.

40 Sobranie dukhovenstva i tserkovnykh starost tserkvi g. Arkhangel'ska po voprosu ob ustroenii prikhodskoi zhizni. Arkhangel'sk, 1906. P. 16-17.

41 The Vladimir congress, for example, cited the widely disseminated substance of the Riga assembly (GAVO. F.556. Op.1. D.4423. L.7). Its deliberations continue to resonate. See, for example: Vasilev A. Pervoe iavlenie voskresaiushchei sobornosti. Rizhskii eparkhial'nyi sobor 29 sentiabria -6 oktiabria 1905 g. // Pravoslavnaia obshchina. 1998. No.44. P. 88-108. 
The people here are used to elections and have long relished the thought of having elected pastors. Of course, this right of election should be given to all parishioners who have reached legal age, without regard to rank or status, because in Christ's Church all are equal. And it is impossible to deny this right to women. As mothers of families, they bear particular significance in the upbringing of the children of the Orthodox Church; among them many are recognized by the Church to be saints, who during their lifetime contributed to the creation of Christ's Church. And memory of them is now being inculcated in the true children of the Church.

Although the Riga sobor left the final decision on female participation to the individual parish, it raised an important issue and set a major precedent for the Church Council in 1917-1918. Like other congresses, the Riga gathering also emphasized the need to "de-bureaucratize" Church governance:

Everyone feels that our Church life has not been, and is still not, what it should be. The main cause of these sad phenomena must be seen to rest in the fact that conciliarity (sobornost') has been expunged from our Church life and replaced by bureaucratism, which has extinguished the living spirit of the Church... The congresses of the clergy, which are permitted by law, also inevitably will lead to a conciliar governance of the Church, with the participation of the parish clergy and laity.

Concretely, the Riga deputies proposed that the diocesan "sobor of clergy and laity" convene each year (to ensure its continuous role in diocesan governance), and to replace the consistory with a "diocesan council of clergy and laity [eparkhial'nyi sovet dukhovenstva $i$ mirian]" - a striking precursor of what would happen in 1917 and later. The Riga sobor sought ways to rejuvenate religious practice and enhance the Church's appeal (e.g., a shortened liturgy), thereby bolstering the Church's capacity to compete with other confessions ${ }^{42}$.

Even before most congresses had met, a Synodal circular of 28 June 1905 asked diocesan bishops to express their opinion about the diocesan congresses, and this issue figured prominently in the "replies" (Otzyvy) submitted in the ensuing months. Significantly, most bishops expressed a favorable opinion, emphasized the value of congresses as an auxiliary diocesan organ, and proposed to expand their competence and composition. Some prelates, such as Bishop Ioann (Smirnov) of Poltava, specifically urged the inclusion of laity: "The admission of laity to the diocesan and to all-Russian national Church councils is required, above all, by the demand of the true interests of the Church itself, as the full body of Christ and the unity of all its members." Archbishop Dimitrii (Koval'nitskii) of Kherson even proposed that the diocesan "sobor" (adopting the terminology of the influential Riga sobor) have a role in the "election of candidates to be bishop of a diocese" 43 .

As the revolutionary wave crested in late 1905, however, the parish clergy experienced the darker side of laicization: parishioners asserted their power not only over parish finances but also over the local clergy. In a private letter of 21 December 1905 Bishop Nikon of Vladimir described the difficult situation in his diocese: "In some districts of the diocese, the parishioners are compiling resolutions to reduce the gratuities paid to clergy to the most insignificant amounts and to abolish altogether collections in kind." Parish-

42 Rizhskii eparkhial'nyi sobor // Rizhskie eparkhial'nye vedomosti. No.20 (15.10). P.911-938; No. 21 (1.11). P.961-990; No.22 (15.11); No.22 (15.11). P.1018-1035; No.23 (1.12). P.1046-1091; No. 24 (15.12). P. 1097-1152.

43 Otzyvy eparkhial'nykh arkhiereev... Vol. 1. P.922, 1007. 
ioners, he complained, also refused to pay the obligatory levies to fund diocesan schools and administration: "In some parishes the church elders (tserkovnye starosty) categorically refuse to deliver church levies to the superintendent for general diocesan needs" 44 . When the consistory proposed to regard such parish resolutions null and void, Nikon confirmed its decision, and issued a secret order to parish clergy that they were not to sign such parish resolutions - which treat the gratuities as a tax, whereas the Church has always regarded them as voluntary donations ${ }^{45}$. Reports of these conflicts found their way into the diocesan press. For instance, the diocesan gazette in Vladimir observed that "one of the signs of the [peasantry's] dissatisfaction with the clergy is the attempt in some areas to reduce the funding for clerical staffs in the village" 46 . The reports were not confined to the diocesan gazette; one local newspaper reported how a village elder, in the midst of the liturgy, approached the altar "and handed the priest a resolution from the entire parish about a reduction in the gratuities for performing all rites. This so confused the man serving at the altar that it interrupted church services for several minutes" ${ }^{\prime 7}$. Although the clergy recognized that laicization might be an effective way to engage and mobilize zealous believers, they became more circumspect as to how much power, and under what conditions, should be conferred on the laity.

The years between the revolutions of 1905-1907 and 1917 marked a general decline in the congresses. The restoration of order (not only the defrocking of radical priests but the intimidation of liberals and moderates) brought a return to the earlier pattern of congresses that met irregularly and wielded limited competence and composition ${ }^{48}$. The outbreak of World War I initially caused an upsurge of patriotism and piety, and the Orthodox Church - like its counterparts in Western Europe - gave both moral and material support to the war effort ${ }^{49}$. However, as the anticipated "short" war became interminable, with catastrophic debacles and astronomic casualties, amidst scandalous reports of "Rasputinshchina" at the very apex of the Church, even conservative clergy grew restless and renewed demands for reform, most dramatically in a collective memorandum (zapiska) from clerical deputies to the State Duma in August $1915^{50}$. Although the memorandum did not achieve its objective (its recipient, chief procurator, A.D. Samarin, was soon dismissed), it renewed interest in parish reform, and in March 1916 the Synod resolved to "invite diocesan prelates" to organize pastoral assemblies "for a discussion of the parish question" $"$.

The following month bishops across the empire assembled clergy to deliberate the parish question. As in 1905, the clergy easily agreed on the need to improve material sup-

${ }^{44}$ RGIA. F. 796. Op. 205. D. 731. L. 1-1 ob. (Nikon to Flavian, 21 December 1905).

45 GAVO. F. 556. Op. 111. D. 1111. L. 387-388 ob.

46 A. B. Dukhovenstvo i nastoiashchii istoricheskii moment // Vladimirskie eparkhial'nye vedomosti. 1906. No. 4. P. 63.

47 S. Motets. Vladimirskii uezd // Kliaz’ma. 1906. No. 26 (28 January 1906). P. 3.

48 The factor of "confessional competition" also declined: the decree on freedom of confession led to large numbers of "apostasy" (mainly in the western provinces) in 1905 and 1906, but thereafter these steadily dropped. Thus, the per annum number of conversions from Orthodoxy dropped from 138,726 (1905-1906) to $19,122(1907-1911)$ and to 13,146 (1912-1915). See the table in: Werth P. The Tsar's Foreign Faiths. Oxford, 2014. P. 210.

49 Freeze G. L. Voina i reforma: Russkaia pravoslavnaia tserkov'v gody pervoi mirovoi voiny, 19141917 gg. // Vestnik Tverskogo gosudarstvennogo universiteta. 2015. Iss. 1. P. 90-116.

50 Pechat' i dukhovenstvo // Missionerskoe obozrenie. 1915. No. 11. P. 286-298.

51 RGIA. F. 796. Op. 445. D. 223. L. 1-2 (Synodal resolution of 4 March 1916). 
port for themselves, ideally through a regular salary that would eliminate a key source of the perennial conflict with parishioners. As in 1905, most clergy supported the right of parishioners to control local funds, despite the probability that such a change would surely limit the diocesan levies used to finance ecclesiastical schools ${ }^{52}$. In contrast to 1905, however, parish clergy were now much more skeptical about giving parishioners the power to select local clergy - reflecting the experience of 1905-1907 and later years. In Moscow, for example, a council of superintendents warned that "the election of the pastor by parishioners, without question, is not mandated by the canons and spirit of the Orthodox Church, and it is also extremely dangerous for Church life in practical terms"53. A gathering of superintendents in Murom district (Vladimir diocese) also voiced opposition to the parish election of local clergy: "Granting the right of the parish to elect the local staff cannot serve to renew parish life in view of the common people's lack of culture and the lack of available candidates whom they know" ${ }^{54}$. Other priests warned that such a parish reform would lead to lowering the educational level of future priests: "It is impossible not to express this truth: the clergy meets the [proposed] parish reform with great reservation, seeing in it a material lack of support for the primary ecclesiastical schools and seminary. One can foresee that, if the flock is given the right to elect priests, then the rural way of life will lead to the choice a person who will accept a reduction in the gratuities for performing rites" 55 . In the view of many priests, application of the electoral principle to the parish will undermine the pastor's role as "spiritual father" of the flock. Moreover, the difficult conditions now prevailing during the war made this a particularly inauspicious time to launch such reform. One assembly of clergy therefore pronounced the reform "premature" and in any case of no great urgency: "We have lived without such a reform for centuries, and one can live without it for another two or three years" ${ }^{56}$. Given this negative response, the Synod suspended further consideration of the matter ${ }^{57}$.

Those meetings in the spring of 1916 foreshadowed events the following year. The February Revolution received overwhelming support in the Church and soon led to the convening of diocesan congresses all across the country. This time, however, the congresses included not only clergy but laity, who adopted resolutions favoring democratization in the Church as well as far-reaching social and political reform ${ }^{58}$. That unanimity also inspired the removal of unpopular bishops (sometimes because of their Rasputin ties, sometimes because of their imperious style of rule) and even official recognition of the laity's authority (most dramatically, in the "Temporary Parish Statute" adopted by the Synod in June 1917). By the summer, however, the clergy's worst fears about "parish power" had come to pass, as the laity not only refused to pay diocesan levies (needed to

52 The response from Vladimir diocese was even unsympathetic to parish control over the purse, but that may reflect the strongly conservative attitudes of the local prelate, Archbishop Aleksii (Dorodnitsyn). According to diocesan critics in 1917, Aleksii was a domineering prelate, tolerated no open discussion, and engineered the telegram in the name of the diocesan clergy against parish control of the purse. RGIA. F. 796. Op. 189. D. 2229/v. L. 271.

${ }^{53}$ RGIA. F. 796. Op. 445. D. 223. L. 9-14 ob.

54 Ibid. Op. 204. Otd. 1. St. 5. D. 104. L. 190-190 ob.

55 Ibid. D. 102. L. 184-184 ob.

56 RGIA. F. 796. Op. 445. D. 223. L. 7-8 (protocol from 25 April 1916).

57 RGIA. F. 797. Op. 84. Otd. 2. St. 3. D.396. L. 121-121 ob. (Synodal resolution of 29 April 1916).

58 Freeze G. L.: 1) Votserkovlenie 1917 goda: Tserkovnyi krizisi prikhodskaia revoliutsiia // Gosudarstvo, religiia, tserkov's v Rossii i za rubezhom. 2019. No. 1-2. P. 30-57; 2) "Gubitel'noe blagochestie": Rossiiskaia tserkov’ i padenie imperii. Sbornik statei. St. Petersburg, 2019. P.267-315. 
support ecclesiastical schools) but also claimed authority to elect - and expel - the local clergy as they saw fit. Although priests sought to resist (sometimes by unionizing), power had devolved from the "Church" to the "church", from the clergy to believers 59 .

\section{References}

Babkin M.A. The Clergy of the Russian Orthodox Church and the February's Revolution of 1917. Moscow, GYY Publ., 2002, 52 p. (In Russian)

Babkin M. A. Parish Clergy of the Russian Orthodox Church and the Overthrow of the Monarchy in 1917. Voprosy istorii, 2003, no. 6, pp. 53-70. (In Russian)

Beglov A.L. State Duma and the Project of Organizing an Orthodox Parish in 1911. Rossiiskaia istoriia, 2016, no. 5, pp. 87-92. (In Russian)

Beglov A. I. The Orthodox Parish of the Russian Empire as an Object of Fiscal Policy of Secular and Ecclesiastical Authorities in the late $19^{\text {th }}$ and early $20^{\text {th }}$ Centuries. Vestnik PSTGU. II: Istoriia, 2014, iss. 3 (37), pp. 56-81. (In Russian)

Evtuhov C. The Church's Revolutionary Moment: Diocesan Congresses and Grassroots Politics in 1917. Russian Culture in War and Revolution, 1914-1922. Eds M. Frame, B. Kolonitskii, S. G. Marks, M. Stockdale, Bloomington, 2014, vol. 1, pp. 377-402.

Firsov S.L. The Revolution of 1917 and Attempts to "Democratize" the Russian Church. Tserkovno-obshchestvennyi vestnik, 2000, no. 6/7, pp. 196-208. (In Russian)

Freeze G. L. Priests and Revolution: The Parish Clergy of Vladimir in 1905. Rethinking the Russian Revolution of 1905 in Transcultural Perspective. Eds F. Fischer von Weikersthal et al. Bloomington, 2013, pp. 1-20.

Freeze G.L. The Parish Clergy in Nineteenth-Century Russia: Crisis, Reform, Counter-Reform. Princeton, Princeton University Press, 1983, 507 p.

Freeze G. L. "Gubitel'noe blagochestie". Rossiiskaia tserkov' i padenie imperii. Sbornik statei. St. Petersburg, European University Press in St. Petersburg, 2019, 352 p. (In Russian)

Freeze G. L. War and Reform: Russian Orthodox Church during the First World War, 1914-1917. Vestnik Tverskogo gosudarstvennogo universiteta, 2015, iss. 1, pp.90-116. (In Russian)

Freeze G. L. "Vladimirskaia eparkhiia: ot tserkovnoi k prikhodskoi revoliutsii." Konfessional'naia politika sovetskogo gosudarstva v 1920-1950e gody. Moscow, ROSSPEN Publ., 2019, pp. 6-16. (In Russian)

Freeze G. L. "Votserkovlenie 1917 goda: Tserkovnyi krizis i prikhodskaia revoliiutsiia," Gosudarstvo, tserkov', religiia v Rossii i zarubezhom, 2019, no. 1-2, pp.30-57. (In Russian)

Kail' M. V. "Revolution in the Church": Discussions on Church Reform and the Smolensk Diocesan's Clergy and Laity in 1917. Tserkovno-istoricheskii vestnik, 2007, no. 14, pp. 163-173. (In Russian)

Leont'ev P. Ya. Revolution in the Church: Congresses of Clergy and Laity in 1917. Tserkov' $v$ istorii Rossii, 1998, vol.2, pp. 214-248. (In Russian)

Leont'eva T. G. Faith and Progress: Orthodox Rural Clergy of Russia in the Second Half of the $19^{\text {th }}$ Century - early $20^{\text {th }}$ centuries. Moscow, Novii khronograf Publ., 2002, 266 p. (In Russian)

Mironov B. N. Social History of Imperial Russia 1700-1917. 2 vols. Vol. 1. Boulder, Westview Press, 2000, $562 \mathrm{p}$.

Pavlenko T. A. Protest Movement of Orthodox Seminaries during the First Russian Revolution of 1905-1907. Diss. ... kand. ist. nauk. St. Petersburg, 2009, 414 p. (In Russian)

Pisiotis A. K. Orthodoxy versus Autocracy: The Orthodox Church and Clerical Political Dissent in Late Imperial Russia, 1905-1914. PhD. diss. Georgetown University, 2000.

Plamper J. The Russian Orthodox Episcopate, 1721-1917: A Prosopography. Journal of Social History, 2000, vol. 34, pp. 5-34.

Rogoznyi P.G. "Church Revolution" and the Election of Bishops in 1917. Istoricheskie zapiski, 2004, vol. 7(125), pp. 275-322. (In Russian)

Rogoznyi P. G. Tserkovnaia Smuta v Orlovskoi Eparkhii v 1917 g. Riurik, 2004, no. 4, pp. 17-33. (In Russian) Rogoznyi P.G. Church Revolution in the Tver Diocese in 1917 (to Study the Social and Political Struggle in the Russian Orthodox Church). Provintsial'noe dukhovenstvo dorevoliutsionnoi Rossii, 2005, vol.1, pp. 92-106. (In Russian)

${ }^{59}$ Friz G.L. [Freeze, G.L.] Vladimirskaia eparkhiia: ot tserkovnoi $\mathrm{k}$ prikhodskoi revoliutsii // Konfessional'naia politika v 1920-1950e gody. Moscow: ROSSPEN. 2019. P.6-16. 
Smirnova I.E. Diocesan Congresses. Vestnik Tverskogo gosudarstvennogo universiteta, Seriia: Istoriia, 2012, no. 1, pp. 111-119. (In Russian)

Vasil'ev A. The First Phenomenon of the Resurrection of Collegiality: Riga Diocesan Cathedral September 29 - October 6, 1905. Pravoslavnaia obshchina, 1998, no. 44, pp. 88-108. (In Russian)

Werth P. The Tsar's Foreign Faiths. Oxford, Oxford University Press, 2014, 288 p.

Received: March 16, 2019

Accepted: September 9, 2019

Статья поступила в редакцию 16 марта 2019 г.

Рекомендована в печать 9 сентября 2019 г. 